\title{
Remittances, Regional Integration, and Balance of Payments Constrained Growth in El Salvador
}

\author{
Luis Rene Caceres ${ }^{1}$ \\ ${ }^{1}$ Independent Researcher, El Salvador \\ Correspondence: Luis Rene Caceres, 5456 Paseo general Escalon, San Salvador, El Salvador. E-mail: \\ luisrenecaceres@gmail.com
}

Received: December 30, 2020

Accepted: February 23, $2021 \quad$ Online Published: February 25, 2021

doi:10.5539/ijef.v13n3p50

URL: https://doi.org/10.5539/ijef.v13n3p50

\begin{abstract}
This paper presents a reworking of Thirlwall's model of economic growth restricted by the balance of payments for El Salvador, taking into account its trade flows with the other Central American countries and its remittances. The results indicate that there is a restriction on the economic growth of this country determined by the economic growth of the other countries of the subregion. It is also found that the role of remittances in alleviating external restriction is low. Evidence is presented that this restriction can be overcome by increasing the quality of education. The work concludes by pointing out the urgency for Central American countries to substantially improve the quality of their educational systems, as a means of increasing their economic dynamism.
\end{abstract}

Keywords: economic interdependence, human capital, monetary integration, remittances, economic growth

\section{Introduction}

In the economics literature, considerable attention has been given in recent decades to the balance of payments constrained economic growth model (BPCEGM). Originally postulated by Thirlwall (1979), this model is emblematic of post Keynesian literature for the importance it gives to the role of aggregate demand in determining economic dynamism. The demand for goods and services generated by economic growth is manifested in increasing imports and, therefore, the objective of keeping external accounts within prudent limits requires that economic growth does not exceed a given rate. This implies that the balance of payments dictates a ceiling to economic growth.

A higher growth rate can be achieved by increasing exports, by virtue of the space they create in the trade account for additional imports. Economic growth can also be increased by reducing the income elasticity of imports, which is related to the capacity of national production not to be displaced by imports.

The BPCEGM model has undergone various extensions; among them, the work of Nell (2003), which introduced the breakdown of total exports by destination countries, as well as the breakdown of imports by countries of origin, stands out. This allows to appreciate the contribution to the economic growth of a given country as a result of its trade with other countries.

This work develops Nell's model in a direction that has not received attention in the literature, specifically with the introduction of remittances in determining trade flows between a group of countries. This is of special importance in the countries of Central America, which, except for Costa Rica, receive high amounts of remittances.

The proposed model is estimated for the case of El Salvador within the framework of its trade with the other Central American countries, which allows appreciating the role of GDP growth and of the remittances of a given country to alleviate, or increase, the restriction of the balance of payments of another country. This approach represents an original way of appreciating economic interdependence in an integration scheme, in the sense that interdependence reflects the restriction of the balance of payments. Below is a brief overview of the selected literature on the CERBP model. This is followed by the elaboration of the proposed model and the discussion of the data and its characteristics. The model is estimated using cointegration methods and the results are discussed. Then, the role of the quality of education in alleviating the restriction of the balance of payments is analyzed. The work ends with a series of conclusions. 


\section{Review of Selected Literature}

Thirlwall's model has been applied to many countries, with results showing the importance of the balance of payments as a restriction on economic growth. It has been estimated in Latin America, among other nations, for Argentina (Chena, 2014), Brazil (Brito \& McCombie, 2009), El Salvador, (Cáceres, 2018), Mexico (Moreno-Brid, 1999; Loria, 2003), Bolivia (Bismarck et al., 2007) and the Central American countries (Moreno-Brid \& Pérez, 2003; Cáceres, 2018).

Some authors have introduced other variables to investigate problems related to developing countries. Among these, the introduction of capital flows as a means to alleviate the restriction of the balance of payments stands out (Thirlwall \& Hussain, 1982), with results that showed that these flows had a limited role in creating space for economic growth, in by virtue of its reduced magnitude, compared to exports and imports. The same results were obtained by Hussain (1999) in estimates for African countries and by Moreno-Brid (2003) for Mexico. Among other relevant applications, the BPCEGM model developed by Dutt (2002) in the context of uneven development stands out. Bagnai (2016) presented a variation of the Nell (2003) model for the case of Italy and estimated export and import equations between this country and its seven most important trading partners. The aggregation of the estimated parameters allowed estimating the growth rate constrained by the balance of payments.

It should be noted that the role of remittances in the BPCEGM model has received little attention. Cáceres (2018a) represents the only study that analyzes two functions of remittances: one, alleviating the external gap due to its contribution to financing the balance of payments, and the other, widening this gap, given the role of remittances in increasing imports of consumer goods. Cáceres (2018a) also analyzed the determination of the conditions under which remittances would have a negative or positive impact on economic growth and estimated this model for the case of El Salvador with data from 1990 to 2014. The author used aggregate data on exports and imports, which did not allow appreciating the role of specific trading partners in the expansion or partial closure of the balance of payments restriction. This is the theme that is developed in this work.

\section{Methods}

\subsection{Data}

The source of annual data for the period 1992-2017 is the World Bank's World Development Indicators. The average values and standard deviations of the variables are presented on table 1 . All variables are expressed in terms of growth rates, which is denoted by the term Growth, followed by the abbreviation of the name of the corresponding country, or of its remittances. All the variables were subjected to unit root tests using the computation of the extended ADF statistic, with results that indicated that all the variables were stationary at the confidence level of one percent, except GrowthES, which was only stationary at the level of ten percent.

Table 1. Average and standard deviations of variables

\begin{tabular}{lcc}
\hline & Average & Standard deviation \\
\hline Rate of economic growth of: & & \\
Guatemala & 3.6525 & 1.0861 \\
El Salvador & 2.5938 & 1.7651 \\
Honduras & 3.6804 & 2.5858 \\
Nicaragua & 3.3281 & 2.7913 \\
Costa Rica & 4.2873 & 2.0504 \\
United States & 2.4674 & 1.5684 \\
Growth of remittances of: & & \\
Guatemala & 7.8978 & 17.8544 \\
El Salvador & 5.6590 & 0.0902 \\
Honduras & 5.5484 & 18.9678 \\
\hline
\end{tabular}

\section{Analysis}

\subsection{The Model}

Below is an extension to Nell's (2003) model based on the functions of remittances in the external constraint, in the context of an economic integration scheme.

First, country 1 is assumed to have trade relations with a partner in the integration scheme, country 2 , and with the rest of the world, which is denoted as country 3. Imports of country 1 from countries 2 and 3, M2 and M3 
respectively, depend on its GDP Y1 and its remittances R1:

$$
\begin{aligned}
& \log (M 2)=b 1 \log (Y 1)+b 2 \log (R 1) \\
& \log (M 3)=b 3 \log (Y 1)+b 4 \log (R 1)
\end{aligned}
$$

Total imports, M1, are given by: M1 = M2 + M3 .

The growth rate of imports from countries 2 and $3, \mathrm{~m} 2$ and $\mathrm{m} 3$ respectively, are given by:

$$
\begin{aligned}
& m 2=b 1 y 1+b 2 r 1 \\
& m 3=b 3 y 1+b 4 r 1
\end{aligned}
$$

where b1 and b2 represent the income and remittances import elasticities of countries 1 and 2 , and $\mathrm{y} 1$ and $\mathrm{r} 1$ represent the rates of economic growth of country 1 and its remittances.

The growth rate of total imports is given by:

$$
m 1=D(M 1) / M 1=(M 2 / M 1)(D(M 2) / M 2)+(M 3 / M 1)(D(M 3) / M 3),
$$

where $\mathrm{D}$ represent the first difference operator.

Thus:

$$
\begin{gathered}
m 1=w 1 m 2+w 2 m 3 \\
\text { where } w 1=M 2 / M 1 \\
\text { and } w 2=M 3 / M 1
\end{gathered}
$$

Thus, the growth rate of total exports is:

$$
\begin{gathered}
m l=w 1(b 1 y 1+b 2 r 1)+w 2(b 3 y 1+b 4 r 1), \text { or: } \\
m l=y 1(w 1 b 1+w 2 b 3)+r 1(w 1 b 2+w 2 b 4)
\end{gathered}
$$

It is assumed that country's 1 exports to country 2, E2, are determined by country 2's GDP and remittances, while its exports to country 3, E3, are determined only by its GDP:

$$
\begin{gathered}
\log (E 2)=a 1 \log (Y 2)+a 2 \log (R 2) \\
\log (E 3)=a 3 \log (Y 3)
\end{gathered}
$$

Where a1, a2 and a3 represent country 1's export elasticities. In terms of growth rates:

$$
\begin{gathered}
e 2=a 1 y 2+a 2 r 2 \\
e 3=a 3 y 3
\end{gathered}
$$

Total exports, E1, are equal to E1 $=\mathrm{E} 2+\mathrm{E} 3$, and their growth rate, e1, is given by:

$$
D(E 1) / E 1=(E 2 / E 1)(D(E 2) / E 2)+(E 3 / E 1)(D(E 3) / E 3)
$$

Thus: $\mathrm{e} 1=\mathrm{w} 3 \mathrm{e} 2+\mathrm{w} 4 \mathrm{e} 3$

Where:

$$
\begin{aligned}
& w 3=E 2 / E 1 \\
& w 4=E 3 / E 1
\end{aligned}
$$

therefore:

$$
e 1=w 3 a 1 y 2+w 3 a 2 r 2+w 4 a 3 y 3
$$

Remittances have and additional role, that of increasing imports, given that they contribute to lessen balance of payments constraint on growth: $\mathrm{M} 1=\mathrm{E} 1+\mathrm{R} 1$

And thus:

$$
D(M 1) / M 1=(E 1 / E 1+R 1)(D(E 1) / E 1)+(R 1 / E 1+R 1)(D(R 1) / R 1)
$$

In terms of growth rates:

$$
m 1=w 5 e 1+w 6 r 1
$$

where:

$$
\begin{aligned}
& w 5=E 1 / E 1+R 1 \\
& w 6=R 1 / E 1+R 1
\end{aligned}
$$


Thus an expression for $\mathrm{m} 1$ can be written as:

$$
m 1=w 5(w 3 a 1 y 2+w 3 a 2 r 2+w 4 a 3 y 3)+w 6 r 1
$$

This expression is also equal to:

$$
y 1(w 1 b 1+w 2 b 3)+r 1(w 1 b 2+w 2 b 4)
$$

Thus, an expression for $\mathrm{y} 1$ is:

$$
y 1=\frac{w 5(w 3 a 1 y 2+w 3 a 2 r 2+w 4 a 3 y 3)-\mathrm{r} 1(w 1 b 2+w 2 b 4-w 6)}{w 1 b 1+w 2 b 3}
$$

The above equation shows that the growth rate of country 1 is positively determined by the growth rates of the economies of countries 2 and 3, w5w3a1y 2 and w $5 \mathrm{w} 4 \mathrm{a} 3 \mathrm{y} 3$, respectively. Country 1 's growth rate also receives growth impacts from remittances, one positive, r1w6, which results from the contribution of its remittances to reducing the balance of payments restriction, and another negative, $\mathrm{r} 1(\mathrm{w} 1 \mathrm{~b} 2+\mathrm{w} 2 \mathrm{~b} 4)$, that results from the role of remittances in determining imports from countries 2 and 3. Another positive impact originates from the contribution of remittances from country 2 , w5 w3a $2 \mathrm{r} 2$.

The above equation shows that the growth rate of country 1 is positively determined by the growth rates of the economies of countries 2 and 3, w5w3a1y 2 and w $5 \mathrm{w} 4 \mathrm{a} 3 \mathrm{y} 3$, respectively. Country 1 's growth rate also receives growth impacts from remittances, one positive, r1w6, which results from the contribution of its remittances to reducing the balance of payments restriction, and another negative, $r 1(w 1 b 2+w 2 b 4)$ that results from the role of remittances in increasing imports from countries 2 and 3 . Another positive impact originates from the contribution of remittances from country $2, \mathrm{w} 5 \mathrm{w} 3 \mathrm{a} 2 \mathrm{r} 2$.

Moreover, it can be seen that the contributions of countries 2 and 3 to the growth of country 1 increase as w3 and w4 increase, that is, in proportion to the exports of country 1 to those countries; it can be expected that they also increase when country 1 's exports manufactured goods to them, since in this case the values of a2 and a3 will be high. It should be noted that the economic growth of country 1 will tend to be greater when its import income elasticities, $\mathrm{b} 1$ and $\mathrm{b} 3$, are low.

These results highlight the great importance of the magnitude of trade flows between countries, as well as the relevance of industrialization and the export of manufactured goods, which is promoted and facilitated in integration schemes between developing countries. It must be emphasized that a country that exports primary products to another from which it imports manufactured goods has an inherent disadvantage in the structure of its international trade. In integration schemes among developing countries, trade flows are largely made up of manufactured goods, which avoids falling into a circle of "uneven development".

A simplified expression of the model can be obtained without disaggregating imports of 1 from 2 and 3 , introducing the assumption that total imports depend on countryl's GDP and remittances:

$$
M 1=b 5 \log (Y 1)+b 6 \log (R 1)
$$

In terms of growth rates:

$$
m 1=b 5 y 1+b 6 r l
$$

As in the previous case, the rate of growth of country'1s total exports is equal to

$$
e 1=w 3(a 1 y 1+a 2 r 2)+w 4 a 3 y 3
$$

The external constraint identity gives rise to the expression for $\mathrm{m} 1=\mathrm{w} 5 \mathrm{e} 1+\mathrm{w} 6 \mathrm{r} 1$,

And given that $\mathrm{m} 1$ is equal to $\mathrm{b} 5 \mathrm{y} 1+\mathrm{b} 6 \mathrm{r} 1$

This expression is obtained:

$$
b 5 y 1+b 6 r 1=w 5 e 1+w 6 r 1
$$

and solving for $\mathrm{y} 1$ :

$$
y 1=(w 5 e 1+w 6 r 1-b 6 r 1) / b 5
$$

Introducing in the previous expression the value of $\mathrm{e} 1$, it is obtained that:

$$
y 1=\frac{w 5(w 3(a 1 y 2+a 2 r 2)+w 4 a 3 y 3)+r 1(w 6-b 6)}{b 5}
$$

In this case, the economic growth of country 1 depends on the economic dynamism of country2's GDP and remittances, while its remittances will have a positive impact if w6 is higher than b6, which points to the 
importance of remittances going to the consumption of goods produced in country 1 , so that the propensity to import out of remittances, b6, is low. Furthermore, the greater the income elasticities of exports, a1, a2, and a3, the higher the rate of economic growth, which denotes the importance of the export of manufactured goods. The growth rate will tend to be high also to the extent that the income elasticity of imports of country 1, b5, is low.

If countries 1 and 2 do not receive remittances, the previous expression reduces to:

$$
y 1=\frac{w 5(w 3 a 1 y 2+w 4 a 2 y 3 e 2)}{b 5}
$$

Which is the expression of the original Thirlwall model.

\subsection{Estimation of the Model.}

The reduced expression of the model is given by:

$$
y 1=G o+G 1 y 1+G 2 y 2+G 3 y 3+G 4 r 1+G 5 r 2
$$

Where $y 1, y 2$ and $y 3$ represent the growth rates of the economies of countries 1, 2 and 3; the latter represents the world economy, which in the estimations are represented by the United States economy, and r1 and $\mathrm{r} 2$ represent the growth rates of remittances received by countries 1 and 2 .

The expression above can be expressed as the following unrestricted error correction model:

$$
\begin{gathered}
D y 1=A o+A 1 y 1(-1)+A 2 D(y 2)+A 3 D(y 3)+A 4 D(r 1)+A 5 D(r 2)+A 6 y 2(-1)+A 7 y 3(-1)+ \\
A 8 r 1(-1)+A 9 r 2(-1)
\end{gathered}
$$

Where the letter $\mathrm{D}$ denotes the first difference of the respective variable and, therefore, represents the short-term adjustments of the growth rate of the economy of a given country in response to the behavior of the variables in first differences; the coefficients of the variables with one year of lag represent the long-term impacts. Long-term multipliers are computed by dividing the coefficients of the lagged variables by the coefficient of y1 (-1).

Prior to the estimation of the error correction model indicated above, cointegration tests were carried out following the Johansen method to detect the existence of cointegration between the variables, with results that indicated the existence of two cointegration vectors. Cointegration equations were estimated according to the Fully Modified Least Squares methodology of Phillips and Hansen (1990). The Phillips and Hansen cointegration methodology applied to an error correction model is valid even when the variables are $\mathrm{I}(0)$, and has the advantage of correcting for the endogeneity of the variables. The estimations followed Hendry's approach of starting from the general to the specific until estimating the most parsimonious equation.

The dependent variable is the increase in the growth rate of El Salvador, which is expressed in terms of the growth rates of the other Central American countries and the USA, and the growth rates of their remittances and those of Guatemala and Honduras. The results of the most parsimonious equation are presented in Table 2.

All the variables have coefficients with the expected signs. The largest short-term multipliers correspond to the growth of the Costa Rican economy, followed by the growth of the Guatemalan one, while the short-term multiplier of US economic growth is negative. The result that the Honduran economy influences El Salvador's economic growth only in the short term could be explained by the series of recessions that the Honduran economy experienced in the period, a total of four. The largest long-term coefficient corresponds to the USA, followed by Guatemala, Costa Rica and Nicaragua, an order that reflects the importance of the amounts of Salvadoran exports to those countries.

These results indicate that El Salvador's economic growth is restricted by the dynamism of the US economy and of the other Central American economies; the implication is that as these economies grow, the balance of payments constraint becomes less restrictive, due to the increase in Salvadoran exports to these countries. The point to stress is that in the Central American countries there is a restriction on economic growth due to the regional balance of payments.

The growth of remittances received by El Salvador has negative short and long-term coefficients. This is consistent with results presented by various authors for various countries in the sense that remittances have negative impacts on economic growth which indicates that remittances accentuate the balance of payments restriction as they increase the demand for imports to a greater extent. that its contribution to reducing the trade deficit.

This can be associated with the extreme openness of the Salvadoran and Central American economies, which has resulted in the production of tradable goods being largely displaced by imports, so that the increase in private consumption generated by remittances is addressed with imports (Caceres, 2017).The growth of remittances 
from Guatemala shows a positive coefficient in the long term and the growth of those from Honduras has a positive coefficient only in the short term. It should be noted that the remittance coefficients are much lower than the coefficients of economic growth.

Table 2. Balance of payments economic growth in El Salvador

de El Salvador. Dependent variable: D(GrowthES)

\begin{tabular}{|c|c|c|c|c|}
\hline Variable & Coefficient & Std. Error & t-Statistic & Prob. \\
\hline GROWTHES(-1) & -0.954602 & 0.039307 & -24.28606 & 0.0000 \\
\hline D(GROWTHUS) & -0.271293 & 0.043787 & -6.195725 & 0.0003 \\
\hline GROWTHUS(-1) & 0.433911 & 0.043770 & 9.913382 & 0.0000 \\
\hline D(GROWTHGUA) & 0.231675 & 0.052043 & 4.451600 & 0.0021 \\
\hline GROWTHGUA(-1) & 0.356045 & 0.073840 & 4.821830 & 0.0013 \\
\hline D(GROWTHHON) & 0.409650 & 0.020459 & 20.02288 & 0.0000 \\
\hline GROWTHNI(-1) & 0.134734 & 0.031456 & 4.283290 & 0.0027 \\
\hline D(GROWTHCR) & 0.456012 & 0.028787 & 15.84091 & 0.0000 \\
\hline GROWTHCR(-1) & 0.183896 & 0.029957 & 6.138672 & 0.0003 \\
\hline D(GROWTHREMREALES) & -0.124080 & 0.010206 & -12.15718 & 0.0000 \\
\hline GROWTHREMREALES(-1) & -0.063229 & 0.013666 & -4.626738 & 0.0017 \\
\hline GROWTHREMREALGUA(-1) & 0.013901 & 0.002489 & 5.585259 & 0.0005 \\
\hline GROWTHREMREALHON(-1) & -0.013956 & 0.005623 & -2.482178 & 0.0380 \\
\hline D(GROWTHREMREALHON) & 0.038745 & 0.003445 & 11.24775 & 0.0000 \\
\hline CUALI1 & 5.252586 & 0.331802 & 15.83049 & 0.0000 \\
\hline $\mathrm{C}$ & -1.294429 & 0.157880 & -8.198824 & 0.0000 \\
\hline R-squared & 0.994164 & & & \\
\hline
\end{tabular}

Long-term multipliers are calculated by dividing the coefficients of the growth rates lagged one year by the coefficient of GrowthES(-1). With that base the following equation was obtained:

$$
\begin{aligned}
\text { GrowthES } & =0.4545 \text { GrowthUS + 0.3729GrowthGUA + 0.1411GrowthNI+ 0.1925GrowthCR } \\
& -0.0665 \text { GrowthremES + 0.0146GrowthremGUA- 0.0147GrowthremHON }
\end{aligned}
$$

The contributions of the Central American countries to the Salvadoran economic growth are of high magnitude and in each period their sum exceeds the contribution of the US economy. It must be added that Costa Rica was the Latin American country whose economy decreased the least in the global crisis of 2008-2009, which must have contributed to avoiding deeper recessions in the other countries. After those years of crisis, the Costa Rican economy recovered at a faster rate than that of the other countries of the isthmus, contributing to the economic recovery of the subregion.

The previous results show that the closer two countries are, the greater the volume of reciprocal trade (greater w3 and w4) than if they were distant, by virtue of the gravity model, and, therefore, greater would be the impact multiplier between countries. Furthermore, the greater the proportion of manufactures in its exports, the greater the multiplier, given that $\mathrm{a} 1$ and $\mathrm{a} 2$ will be of greater magnitude than if the country exported primary goods. This explains the high values of the multipliers El Salvador receives from Guatemala, since they are the main partners in the amounts of trade and have the shortest distance between trading partners in Central America. El Salvador has with the USA the largest amount of exports, which to a large extent are made up of primary goods, as opposed to goods traded in the subregion, which are mainly manufactured goods. This would explain that the multiplier received from the USA is of the same order of magnitude as that of Guatemala, even though the volume of trade is twice as large. There is evidence that, since trade between the Central American countries is mainly made up of manufactured goods, the expansion of their exports to the rest of the subregion contributes to the increase in the share of value added in the manufacturing sector and, therefore, slows down deindustrialization (Cáceres, 2017a). This result points to the advantage of regional integration over unilateral opening.

\section{Discussion}

\subsection{Importance of Human Capital in Economic Growth in Latin America}

The previous analysis showed that the increase in economic growth of a given Central American country is constrained by economic growth in the US and in the other countries of the subregion. Therefore, it is especially 
important to know the variables that determine growth in each country in order to be in better position to promote their growth and overcome the restriction on the balance of payments.

An extensive literature is dedicated to the role the of the quality of education in imparting dynamism to economic growth. Jamison, Jamison and Hanushek (2007) showed that the quality of education, measured as the results in international tests, increases the rate of economic growth through its impact on increasing the rate of technological progress; while Sheridan (2014) showed that the technological content of a country's exports depends on the availability of high-quality human capital, with subsequent repercussions on growth.

Regarding Latin American countries, Hanushek and Woessmann (2009) estimated equations expressing the per capita economic growth in terms of the scores from the tests of the Second Regional Study on Quality of Education, SERCE, that took place in 2005, with results that indicated that the average country scores for these tests were the most important determinants of economic growth in Latin America.

In view of its influence on economic growth, the quality of education emerges as a valuable instrument to alleviate the restriction of the balance of payments on growth and to impart sustained dynamism to the Central American economies. The changes to the Thirlwall model required to introduce the quality of the of education are investigated below.

\subsection{Quality of Education and Quality of Exports}

To analyze the way in which the quality of education affects the Thirlwall model, the starting point is the model of Porcille, Dutra and Meirelles (2007), who argue that the exports of a given country grow to the extent that their quality increases, which depends on the country closing the technology gap in relation to developed countries. Below is a simplified reworking of this model.

Exports, $\mathrm{X}$, are given by:

$\mathrm{X}=\mathrm{aW}$, where $\mathrm{W}$ is the export quality index and a is the elasticity of export quality.

Export growth equals: $\mathrm{x}=\mathrm{aw}$, where $\mathrm{w}$ is the growth rate of export quality.

The GDP, $\mathrm{Y}$, of the economy in question is determined by exports:

$\mathrm{Y}=\mathrm{cX}$, and its growth rate is: $\mathrm{y}=\mathrm{cx}=\mathrm{caw}$

Porcille, Dutra and Meirelles (2007) make the assumption that the quality of exports grows as the country in question manages to close the technology gap with developed countries; however, it can be assumed here that the growth rate of the quality of exports depends on the quality of education $\mathrm{H}: \mathrm{w}=\mathrm{vH}$

And therefore:

$\mathrm{y}=\mathrm{cavH}$, which is the equation to be estimated in the next section.

\subsection{Quality of Education and Economic Growth in Latin America}

The quality of education is represented by the national average scores in reading and mathematics in the Third Regional Study of Quality of Education (Unesco / TERCE, 2016), prepared by the Latin American Laboratory for Assessment of the Quality of Education (IICE), that took place in 2013 and included 15 countries in the region and had a sample of 67,000 students. Cáceres (2018b) has presented an exhaustive analysis the role of several measures of education quality in the determination of Latin American countries' growth. Here only one equation will be estimated, with a sample that was reduced to 11 countries due to data limitations. The economic growth variable, Growth, represents the average of economic growth per capita for the period 2005-2012, computed based on data from ECLAC (2013). The estimated equation expressing the rate of economic growth of the sample of 11 Latin American countries in terms of their scores in reading in sixth grade and that qualitative variable Cuali that represents the 2009 recession, is the following:

Growth $=-6.2387+2.7581$ Cuali +0.0166 SixthGradeReading

$\mathrm{R} 2=0.81$

This equation validates the previous analysis that showed that quality of education determines economic growth.

This equation can be substituted in the equation that expressed the economic growth of El Salvador in terms of the economic growth of the USA and from the other Central American countries, to obtain an expression for the increase in the growth of the Salvadoran economy in terms of increases in the quality of education in the other countries. If the contributions of remittances are discarded, the following expression is obtained: 
$\mathrm{D}($ GrowthES $)=0.4716 \mathrm{D}($ GrowthUS $)+0.0062 \mathrm{D}($ Sixth ReadingGUA $)+$

$0.0032 \mathrm{D}$ (Sixth Reading CR) + 0.0023D(Sixth ReadingNI)

The increase in El Salvador's growth rate can also be expressed in terms of sixth grade math scores:

$\mathrm{D}($ GrowthES $)=0.4545 \mathrm{D}($ GrowthUS $)+0.0057 \mathrm{D}($ Sixth MathGUA $)$

$+0.0030 \mathrm{D}$ (Sixth MathCR $)+0.0021 \mathrm{D}($ Sixth MathNI $)$

Given that there is a negative relationship between the Gini coefficients and the sixth-grade mathematics scores (Note 1), (Caceres, 2018), by substitution the previous equation for the growth rate of El Salvador can be expressed in terms of said coefficient:

$\mathrm{D}($ GrowthES $)=0.4545 \mathrm{D}($ GrowthUS $)-0.0400 \mathrm{D}($ GiniGUA $)-0.0147 \mathrm{D}($ GiniNI $)-0.0210 \mathrm{D}($ GiniCR $)$

This last equation indicates that if Guatemala's Gini coefficient decreased by 10 percentage points, El Salvador's economic growth rate would increase by 0.4 percentage points.

The implication is that inequality, as shown by ECLAC (2018), is inefficient, as it punishes the generation of technology and economic dynamism; it must be added, in light of the previous equation, that the inefficiency of inequality has a regional scope.

These results indicate that there is a potential for Central American countries to boost their economies and their economic integration by increasing their quality of education. In other words, the quality of education is a regional public good. A regional commitment in relation to these actions would be a valuable measure to reverse the stagnation trends shown by the economies; it would also be a valuable measure to cope together in the fight against violence.

It should be noted that the quality of education leads to individuals obtaining good jobs, as a consequence of their skills and abilities, and, therefore, they will tend to obtain better wages in the labor market, which is conducive to generating savings. Likewise, for its role in increasing national savings, and especially for its role in facilitating the adoption of technologies, the quality of education contributes to increasing the rate of private investment. It must be emphasized that private investment increases as public sector spending on education increases (Caceres, 2018) (Note 2). Reference should be made to the evidence presented by Tsounta and Osueke (2014) that the results of Latin American countries in the international PISA tests tend to increase as public spending as percentage of GDP increases.

\subsection{Economic Interdependence Through the Quality of Education}

It should be noted that in an economic integration scheme, investment in the quality of education in a given country has positive repercussions in the other member countries, which is especially important in the Central American case. This is analyzed in figure 1. Quadrant 1 shows the positive relationship between spending on education in country 1, Gasto1, and its quality of education, Calid1. Quadrant 2 shows the increase in economic growth in country $1, \mathrm{Cre} 1$, as a result of the increase in its quality of education. In view of the increase in the economic growth of country 1 , its imports from country $2, \mathrm{X} 2$, increase as shown in quadrant 3 . In this way, the positive relationship between Gasto1 and X2 is constructed in quadrant 4; that is, the expenditure in education of country 1 contributes to increase trade flows from country 2 to 1 . The economic growth of country 2 increases as a consequence of the increase in X2, and with the help of the 45 degrees line in quadrant 6 , it is built in quadrant 7 a positive relationship between Gasto1 and the economic growth of country 2, Cre2, while quadrant 8 shows the positive relationship between the growth rates of countries 1 and 2, which implies that the economic growth rates are symmetrical or synchronous.

Quadrant 9 shows that, as a result of the growth of country 2, its tax revenues increase, which gives rise to another round of increases in education spending, and thus quadrant 10 shows a positive and symmetrical relationship between the education expenditures in both countries; that is, the increase in spending in one country induces higher spending in the other.

This figure shows that education spending in a country not only leads to increases its own economic growth and tax revenues, but regionally drives economic growth, tax revenue, and spending on education in other countries. In other words, if the countries agreed to increase their human capital investments in a concerted manner, establishing annual goals for increases in certain budget items in a medium and long-term framework, the purely national benefits would be complemented by spill over benefits received from the other countries. In other words, there are externalities of economic growth resulting from investments in human capital that the member countries of an integration scheme can capitalize on. This result does not take place in the case of unilateral opening. 


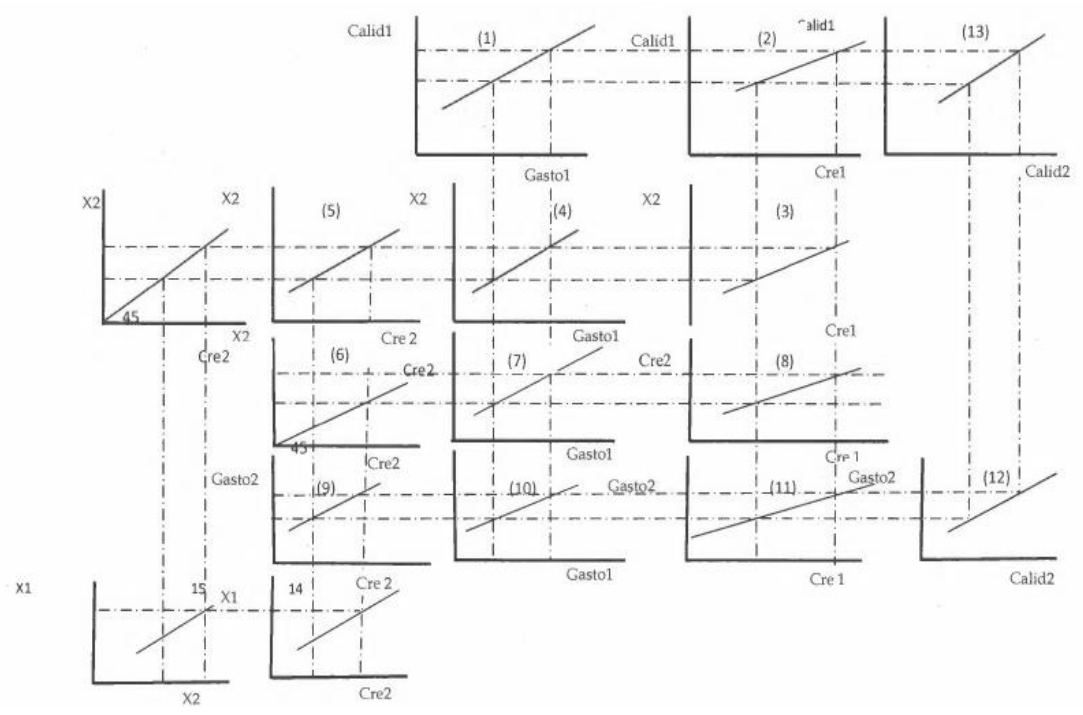

Figure 1. Quality of education and economic interdependence

\subsection{Implications Related to Monetary Integration}

The economic interdependence analyzed in the previous section has implications in the analysis related to the adoption of a common currency among member countries of an economic integration scheme.

Figure 2 presents the Frankel and Rose (1997) model on the conditions for the adoption of a single currency in an integration scheme, in which the abscissa represents the intensity of trade between two countries, (comercio reciproco), and the ordinate represents the correlation between their economic growth rates (correlacion ciclo economico). It is assumed that when a common currency is in effect, as trade increases a reduction in transaction costs occurs and, therefore, the benefits of monetary integration increase. Furthermore, when the correlation between the economies increases, the cost of not having their own currency decreases. These authors argue that the correlation between the economies of two countries is determined by the intensity of reciprocal trade, and that the correlation between growth rates and the goodness of the adoption of a common currency is endogenous to trade flows.

The existence of a growth regime restricted by the balance of payments implies that the economies will tend to experience synchronism in their economic growth rates, since the increase, or decrease, in the growth of each one of them, has impacts in the same direction. in the other economies, given that the trajectory of one economy alleviates, or aggravates, the restriction of the balance of payments of the others. This has implications for the adoption of a common currency, since the tendency to economic synchronism resulting from the restriction of the balance of payments would correct the limitation or problems faced by member countries of a monetary integration scheme resulting from not having their own monetary policy, given that all economies would tend to follow common trajectories in unison, and thus the actions of the regional central bank would be consistent with the national economic cycle.

According to Frankel and Rose (1997), the points on line WW of figure 2 represent the situations in which the benefits of adopting a common currency are equal to the costs; the points above this line denote that the adoption of the common currency is justified, while the points below it indicate that such a measure is not appropriate, since the costs would be greater than the benefits. Point A represents a situation in which the correlation between countries and the intensity of trade are given by $\mathrm{C} 1$ and $\mathrm{T} 1$ respectively, this is a situation in which monetary integration is not justified. By assuming that trade intensity increases to $\mathrm{T} 2$, the increase in exports alleviates the restriction of the balance of payments and, therefore, the correlation between countries increases to $\mathrm{C} 2$, a situation represented by point $\mathrm{B}$, in which the adoption of the common currency is justified.

The magnitude of multipliers between countries depends on w1 and w2, the share of exports from one country to another in its total exports; therefore, increased trade implies that $w$ increase. But the long-term multiplier from one country to another also depends on the income elasticity of its exports; if this elasticity is low, as would be the case when the country exports primary goods, the multiplier will be low and, therefore, the increase in the correlation between countries would be lower than when the country exports manufactured goods, whose export elasticities are of greater magnitude. An extreme case occurs at point D representing the substantial increase in 
trade to T3, but only a slight change in the correlation occurs between countries, to $\mathrm{C} 3$, under the assumption that trade is composed of primary goods. Another case is represented by point $\mathrm{E}$ in which trade increases only to $\mathrm{T} 4$, but the correlation increases to $\mathrm{C} 4$, due to the assumption that exports are made up of manufactured goods.

This shows the importance of analyzing monetary integration in the framework of the economic growth model restricted by the balance of payments and taking into account the nature of the goods that are traded in the integration area. In other words, the convenience of monetary integration is endogenous to the existence of situations of growth restricted by the balance of payments and the composition of trade flows.

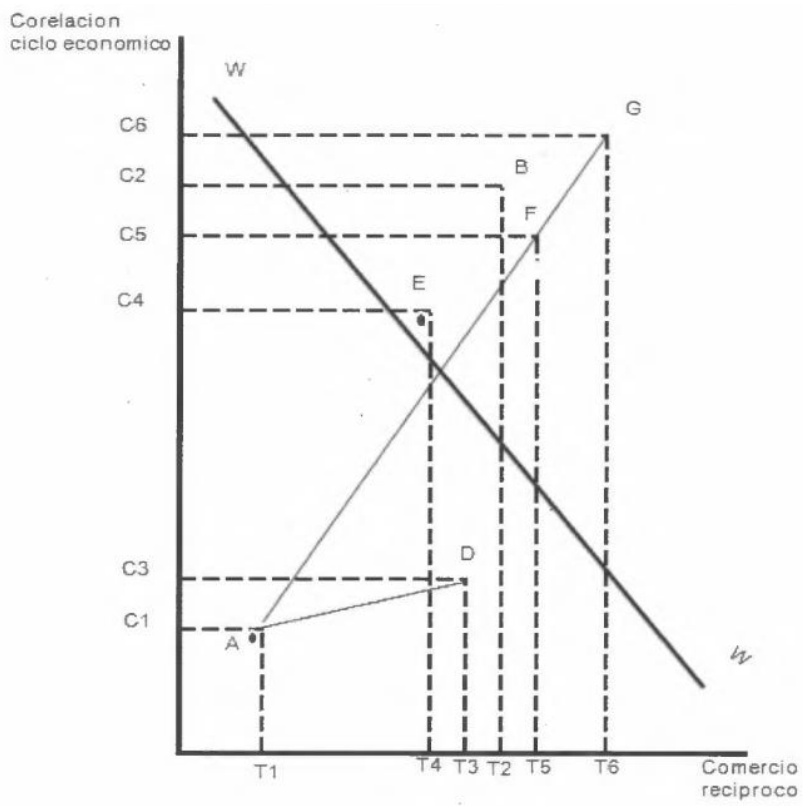

Figure 2. Criteria adoption of common currency

Of particular importance is the introduction of the assumption that a member country invests massively in human capital and, consequently, an acceleration of economic growth occurs. This situation is represented by point $\mathrm{F}$ in figure 2, which denotes that trade increases at T5, and the correlation between business cycles increases at C5. Furthermore, the highest level of human capital in the country in question results in leads to a redistribution of income towards more equity (Gonzalez \& Martner, 2012) and, therefore, the purchasing power of the population increases, so that trade increases T6 and the correlation to C6. Likewise, the increase in human capital would increase the national capacity to produce and export manufactured goods, which would be reflected in additional increases in trade and in the correlation to T6 and C6, respectively.

Other interesting cases occur when one or more countries receive capital flows that overcome the balance of payments restrictions and, consequently, the correlation between the growth rates of the countries could decrease.

This shows that the benefits of monetary integration would depend, in addition to the nature of the traded goods and volume of trade, on the national policies of human capital and income distribution. An economic integration program between developing countries that does not undertake large human capital investments is bound to fail.

\section{Conclusions}

The results presented in this work constitute evidence of the validity of the growth model restricted by the balance of payments in El Salvador at a regional level, that is, within the framework of its trade links with the other Central American countries and with the United States, of its remittances and those of other countries in the region. This indicates that the economic dynamism of these countries is determined by the demand of their main trading partners, in a regional model. The result stands out that the remittances that El Salvador receives do not contribute to increasing its economic growth, on the contrary, they reduce it, which denotes that they contribute more to increasing the demand for imports than to alleviating the external restriction. For their part, remittances from Guatemala do promote Salvadoran economic growth, but in a much lower magnitude than that resulting from economic growth. 
The foregoing shows that El Salvador is missing the valuable opportunity to take advantage of remittances to support the development of agricultural production and national manufacturing. On the contrary, the extreme openness of its economy leads to the economic potential of remittances dissipated in imports.

It should be noted that in Latin America, Central American countries have the lowest import tariffs and the lowest rates of economic growth so far since the 1990s, rates well below those experienced in the 1960s and 70 when the import substitution model was in vigor. Furthermore, these countries experienced the deepest economic contractions as a consequence of the global crisis of 2007-2009, and are the economies that showed the slowest subsequent recovery in Latin America, which can be properly attributed to their extreme openness. The excessive opening of economies may well be another manifestation of the "culture" of privilege, which ECLAC (2018) has described, which sacrifices national production and good jobs.

This suggests that the growth model restricted by the balance of payments should be placed in the context of the opening of the economy, since the income elasticity of imports reflects the level of protection from imports. It should be noted that Cáceres (2017b) showed through a Var model that the increase in import tariffs by Central American countries would lead to increase their economic growth rates.

It has also been shown that national economic dynamism depends on the quality of education at the regional level; therefore, attempts to consolidate Central American integration should be oriented towards improving the quality of human capital, as the main investment priority of the public sectors. In this way, economic growth would be stimulated, and violence and irregular emigration, which are the main problems of the subregion, would be reduced.

Continuing with the fiasco of the neoliberal model would mean continuing with economic stagnation and with the export of people. Just as great importance is given in the national economic policy circles to the exchange rate, to the control of inflation, to the facilitation of exports, to the reduction of custom procedures, to the customs union, etc., higher priority should be given to improve the quality of education and the expansion of equal opportunities.

An issue that has received considerable attention in integration schemes is that of the equitable distribution of its costs and benefits. In the context of the results of this work, it is inferred that it is important that all countries improve the quality of their educational systems with a view to reducing national disparities in the levels of social development prevailing in the integration scheme, that is, the investment in human capital can constitute the operational framework to realize the aspiration of achieving the convergence of development levels in Central America.

On the other hand, investment in the quality of education makes it possible to achieve an economic structure that allows achieving a growth model from the inside, which has been a persistent aspiration in the theory of Latin American economic development; likewise, it allows achieving, to a certain extent, autonomy with respect to the world economy, which has also been an aspiration in various latitudes.

The poor educational performance reflects the low tax collection in the region, as well as the opposition to increase it; This is ironic given the benefits that all strata of society would obtain as a result of increasing spending on education, which would lead to a larger economy, with better jobs and higher profits for companies. That is, the opposition to increase the tax revenues that would be destined to increase human capital implies a commitment to the continuation of underdevelopment, poverty, violence, and irregular migration.

It should be noted that the lack of attention to education, as shown in the international tests and in the TERCE, represents a violation of the human rights of a large number of citizens, as regards the Universal Declaration of Human Rights, which stipulates in its article 26 the right to education: "Everyone has the right to education."

Education is a means of obtaining quality employment. Article 23 of the previous Declaration establishes the right to work in these terms: "Everyone has the right to work, to free choice of work, to just and favorable conditions of work and to protection against unemployment."

And its article 3 promulgates the right to life that, for many people, poor, underemployed and unemployed (due to educational deficiencies), is prematurely truncated: "Every individual has the right to life, liberty and security of His person".

Given that people with a low level of education are condemned to a life of poverty and on the margins of society, it is appropriate to quote article number 5 of the Declaration: "No one shall be subjected to torture, or to cruel, inhuman punishment or treatment. or degrading."

It is important to take actions to ensure that international law, which is binding at the national level, prevails and 
thus is used to end the abuse suffered by vulnerable populations. And an important measure would be for these people to resort to regional and international courts to demand that their rights be respected.

In order to advance towards structuring dynamic and social justice economies, the Central American countries could establish, through consultations and agreements between the different political parties, labor unions, civil society and business groups, binding agreements aimed at overcoming recessionary economic trends, and to overcome inequality in its various manifestations and, especially, to end the culture of privilege, as described by ECLAC (2018). Within this framework, special attention deserves the achievement of national fiscal pacts that establish commitments on the origin of the additional tax resources and on the destination of these, as well as the mechanisms of transparency, participation and citizen audit and monitoring.

Among the possible fields of joint action the following stand out: The adoption of a regional commitment to increase the quality of education, the preparation of educational technology content (apps, videos, CDs, etc.) to support students in reaching their expected grade level, and as didactic support especially in areas of special early education, in the education of indigenous populations, etc. The preparation of textbooks, manuals of pedagogical practices aimed at supporting the quality of education; the design and implementation of special education programs; the design and implementation of early childhood education programs; the design and implementation of health programs aimed at combating dengue and zika, and campaigns for the prevention and treatment of HIV-AIDS.

The design and implementation of programs to combat violence against women, as well as the expansion of coverage of childcare centers networks.

Concerted actions in the search for external resources, with the understanding that the international community would contribute the same amount of resources as those additionally contributed by the Central American countries.

Special importance resides in the programs that can be implemented after the covid pandemic; among these the following deserve particular attention:

Physical infrastructure in border areas so as to facilitate trade and generate employment; emergency employment programs; purchase of equipment and vaccinations in a coordinated manner; strengthening public health systems and research facilities; strengthening of college careers in infectiology, epidemiology, and public health, establishment of telemedicine facilities.

This would open a new dimension to Central American integration, a dimension that would allow closing disruptive gaps, promoting equitable social development and making social justice a reality for large groups of Central Americans. This would be a means to stop the economic and social deterioration experienced in the subregion.

The success of the measures is subject to substantial increases in tax revenues, with a view to increasing spending on human capital, with the main purpose of improving the quality of education and thus obtaining the benefits described in this work.

\section{References}

Bagnai, A. (2016). Italy's Decline and the Balance of Pyments Constraint: A Multicountry Analysis. International Journal of Applied Economics, 30. https://doi.org/10.1080/02692171.2015.1065226

Bismarck, J. et al. (2007). The Balance of Payments Constrained Growth Model: Empirical Evidence for Bolivia. Revista de Humanidades y Ciencias Sociales, 3. https://doi.org/10.1590/S1819-05452007000100001

Brito, G., \& McCombie, J. S. L. (2009). Thirlwall's Law and the Long Term Equilibrium Growth Rate: An Application to Brazil. Journal of Post Keynesian Economics, 32. https://doi.org/10.2753/PKE0160-3477320108

Caceres, L. R. (2017a). Desindustrializacion y Estancamiento Economico en El Salvador. Revista de la CEPAL. https://doi.org/10.18356/9c372d5b-es

Caceres, L. R. (2017b). Openness and Economic Stagnation in Central America. Journal of Developing Areas, 57. https://doi.org/10.1353/jda.2017.0021

Caceres, L. R. (2018a). Remittances and Balance of Payments Constrained Growth in El Salvador. In Central America: Essays on Underdevelopment, Riga, Lambert Academis Publishers.

Caceres, L. R. (2018b). Hechos Estilizados sobre la Calidad de Educacion en los Paises de America Latina. Unpublished. 
CEPAL. (2013). Preliminary Overview of the Economies of Latin American and the Caribbean. Santiago de Chile.

Chami, R. et al. (2008). Macroeconomic Consequences of Remittances. Occasional Paper no. 259, Washington DC, International Monetary Fund.

Chena, P. I. (2014). Balance-of Payments-Constrained Growth in Argentina (1976-2006). Journal of Post Keynesian Economics, 36. https://doi.org/10.2753/PKE0160-3477360406

Dutt, A. K. (2002). Thirlwall's Law and Uneven Development. Journal of Post Keynesian Economics, 24. https://doi.org/10.1080/01603477.2002.11490331

Gouvea, R. R., \& Lima, G. T. (2007). Structural Change, Balance of Payments Constraint and Economic Growth: Evidence from the Multi-Sectoral Thirlwall's Law. Unpublished.

Hussain, M. N. (1999). The Balance-of-Payments Constraint and Growth Rates Differences Among African and East Asian Economiies. working paper, Abijan, African Development Bank. https://doi.org/10.1111/1467-8268.00006

Jamison, E. A., Dean, J. D., \& Hanushek, E. A. (2007). The Effects of Education Quality on Income Growth and Mortality Decline. Economics of Education Review. https://doi.org/10.1016/j.econedurev.2007.07.001

Loayza, N., Fajnzylber, P., \& Calderon, C. (2005). Economic Growth in Latin America and the Caribbean. Washington DC, Banco Mundial. https://doi.org/10.1596/0-8213-6091-4

Loria, E. (2003). The Mexican Economy: Balance of Payments-Constrained Growth Model: The Importance of the Exchange Rate. Journal of Post-Keynesian Economics, 25.

Moreno-Brid, J. C. (1999). Mexico's Economic Growth and the Balance of Payments Constraint: A Cointegration Analysis. International Review of Applied Economics, 13. https://doi.org/10.1080/026921799101634

Moreno-Brid, J. C. (2003). Capital Flows, Interest Payments and the Balance-of Payments Constrained Growth Model: A Theoretical and Empirical Analysis. Metroeconomica, 54. https://doi.org/10.1111/1467-999X.00170

Nell, K. (2003). A Generalised Version of the Balance of Payments Growth Model: An Application to Neigbouring Regions. International Review of Applied Economics, 17. https://doi.org/10.1080/0269217032000090478

Ozturk, I., \& Acaravci, A. (2010). An Application of Thirlwall's Law to the South African Economy: Evidence from ARDL Bounds Testing Approach. South African Journal of Business Management, 4.

Phillips, P. C. B., \& Hansen, B. E. (1990). Statistical Inference in Instrumental Variables Regressions with I(1) Processes. Review of Economic Studies, 57. https://doi.org/10.2307/2297545

Porcile, G., Dutra, M. V., \& Meirelles, A. J. A. (2007). Technology Gap, Real Wages, and Learning in a Balance-of-Payments-Constrained Growth Model. Journal of Post-Keynesian Economics, 29. https://doi.org/10.2753/PKE0160-3477290306

Thirlwall, A., \& Hussain, M. N. (1982). Balance of Payments Constraint, Capital Flows and Growth Rate Differences Between Developing Countries. Oxford Economic Papers, 34. https://doi.org/10.1093/oxfordjournals.oep.a041565

Thirlwall, A. (1979). The Balance of Payments Constraint as an Explanation of International Growth Differences. Banca Nazionale del Lavoro Quarterly Review, 128.

Unesco (2016). Tercer Estudio Regional Comparativo y Explicativo. TERCE Santiago de Chile. https://doi.org/10.22201/iisue.24486167e.2016.152.57607

\section{Notes}

Note 1. The equation is:

Sixth grade mathematics score $=1078.073-7.0120 \mathrm{GINI}$

$\mathrm{R} 2=0.38$ 
Note 2. The estimated equation is:

Private investment $=5.7559+10.7224$ Cuali +2.1946 EducationExpenditure

$$
\text { (1.36) (2.55) }
$$

$\mathrm{R} 2=0.71$

Cuali takes the value of 1 in the case of Chile and of zero in all other cases.

\section{Copyrights}

Copyright for this article is retained by the author(s), with first publication rights granted to the journal.

This is an open-access article distributed under the terms and conditions of the Creative Commons Attribution license (http://creativecommons.org/licenses/by/4.0/). 